Mosul Journal of Nursing, Vol. 7, No. 2, 2019 ( 92-214 )

Mosul Journal of Nursing

www.mjn.mosuljournals.com

\title{
Knowledge, attitudes and practices for dialysis nursing staff regarding personal protection means from hospital acquired in Mousl hospital
}

\author{
Article information \\ Article history: \\ Received September 24, 2019 \\ Accepted Januarry 8, 2020 \\ Available online December 31, 2019 \\ DOI: 10.33899/mjn.2021.168676 @2020, College of Nursing, University of Mosul. \\ Creative Commons Attribution 4.0 International License \\ https://mjn.mosuljournals.com/article 168676.html \\ Aayed A. Bny Uoda ${ }^{1}$
}

\begin{abstract}
Background: This study intended to assess knowledge, attitudes, and practices regarding standard precautions concerning Hospital acquired protection (HAIs) among hemodialysis nurses in hemodialysis centers in Mosul

Methods: A descriptive study was carried out during the period from 18th of February 2019until 14th of February 2019. A non - probability purposive sample consisting of 25 nurses .

Results: there were a total of 25 hemodialysis nurses in hemodialysis centers in Mosul. All agreed to participate in the study. Although $72 \%$ of the nurses knew that their hands could be a source of infection associated with health care, only $36 \%$ of the nursing staff washed their hands before contacting another used $92 \%$ by the nursing staff when contacting the patient in the dialysis unit and $40 \%$ of nursing staff also wore masks when contacting patient.

Gloves were actually used by $98 \%$ of the nurses. $46 \%$ of the nurses were usually wearing masks when contacting a patient. Books and journals were the main source of information about (HAI) among $\% 52$ of the nurses.

conclusions: The nurses' knowledge of healthcare-related illnesses did not fulfill this purpose because some of the nursing staff did not adhere to personal hygiene practices.

Recommendations: the necessary training programs for nurses in hemodialysis centers on the promotion of hygiene standards and optimal use of personal protection against hospital infection.

Keyword: Knowledge, attitude , practices , nursing staff, dialysis, hospital acquired, infections
\end{abstract}

${ }^{1}$ Senior college nurse/ Directorate of Health, Mosul, Iraq 


\section{Mosul Journal of Nursing, Vol. 7, No. 2, 2019 ( 92-214 )}

\section{Introduction:}

Hemodialysis (HD) is one of several renal replacement therapies (RRTs) used in the treatment of renal failure to remove excess fluids and waste products and to restore chemical and electrolyte imbalances.

Hemodialysis today moves towards innovative techniques, biomaterials and devices with an absolute need for solid evidence around every new treatment or technology (Shimokura et al., 2011). The number of patients being treated for end stage renal disease (ESRD) globally was estimated to be $2,786,000$ at the end of 2011 and, with a 6-7\% growth rate, continues to increase at a significantly higher rate than the world population. Of these 2,786,000 ESRD patients, approximately $2,164,000$ were undergoing HD treatment (Fresenius Medical Care, 2012 .(The hemodialysis procedure started as an external vascular circuit through which the patients' blood is transferred into polyethylene tubing to the dialysis filter or membrane (dialyzer) via a mechanical pump. The patients' blood then passes through the dialyzer on one side semi-permeable membrane and is returned to the patient. The dialysate solution, which consists of purified water and electrolytes, is pumped through the dialyzer counter current to the flow of blood on the other side of the semipermeable membrane. In most cases, systemic anticoagulation (with heparin) is used to prevent clotting of the hemodialysis circuit. (Jones, Brenda, 2009; and Longo, 2012 .(Nursing staff must take adequate precautions and implement appropriate practices that will substantially reduce the risk of workplace transmission of blood borne infection to patients and staff within the dialysis units. Various evidence-based guidance have been published for the prevention of healthcare-associated infections (HAIs) in all HD settings in order to globalize and share the evidence, as centers for disease control CDC recommendations, Active pharmaceutical ingredients committee APIC guide to the elimination of infections in HD (2010) and kidney disease improving global outcomes
(KDIGO) Clinical Practice Guidelines, by (Elamin, \& Abu-Aisha, 2011).All equipment, including the front of the dialysis machine, should be considered contaminated after a patient dialysis session. (Papadakis M, McPhee, 2014) emphasized that cleaning and disinfecting non-critical surfaces in patient-care areas are part of standard precautions, and it is important for frequently touched surfaces, especially those closest to the patient, that are most likely to be contaminated (e.g., HD chairs, HD machines, carts, bedrails, bedside tables, commodes, doorknobs, sinks, surfaces and equipment in close proximity to the patient).

During the dialysis session, if the external transducer protector filter becomes wet with blood or fluid, it must be replaced immediately and the transducer inspected. If blood or fluid is visible on the side of the filter that connects to the machine, inspection of the internal hardware of the dialysis machine must be performed prior to use on subsequent patients(Drummer, 2014). A qualified biomedical engineer or a trained and qualified dialysis $\mathrm{HCW}$ must inspect the external and internal hardware for blood or fluid intrusion. If the equipment has been contaminated with either blood or fluid, the internal lines and filter must be replaced and the external machine connector port disinfected with an intermediate level disinfectant such as 1:100 bleach solution. (Yu \& Chiang, 2010:Zhang et al., 2012: Pozzetto et al., 2014)

Regarding waste management, needles should be disposed of in closed, unbreakable containers that should not be overfilled. A "no touch" technique should be used to drop the needle into the container, as it is likely to have a contaminated surface. If this is difficult due to the design of the container, staff should complete patient care before disposing of needles. The used extracorporeal circuit (bloodlines and dialyzer) should be sealed as effectively as possible before transporting it from the dialysis station in a fluid-tight waste bag or leak-proof container. If it is necessary to drain the circuit, or to remove any 


\section{Mosul Journal of Nursing, Vol. 7, No. 2, 2019 ( 92-214 )}

components for reprocessing, this should be done in a dedicated area away from the treatment and preparation areas (APIC, 2010).

Nurses must be skilled in renal nursing, maintain a high standard of clinical practice, have excellent communication skills, and develop their individual leadership and management abilities. Nurses should be involved in multi professional discussions where decisions are made about changes in patient treatment. In addition, nurses require the clinical skills and competencies to manage renal patients in different stages of their illness and on particular RRT modalities. (Bouallègue et al., 2013).

Many infection control measures, such as appropriate hand hygiene, consistent use of aseptic technique, cleaning and disinfection practices are simple and of low-cost, but require staff accountability and behavioral change, in addition to improving staff education, reporting and surveillance systems. (Benson \&Powers, 2011). Infection control and prevention is the responsibility of the nurse, and represents an integral element of patients' safety program (Liza, Kim, Rose \& Stephen, 2012). It encompasses the processes and activities which identify and reduce the risks of acquiring and transmitting endemic or epidemic infections among individuals (David \& Famurewa, 2010). Therefore, nurses should have professional and ethical responsibilities to make sure that their knowledge and skills regarding infection control are up-to-date and they practice safely and competently at all times (Eskander, Morsy \& Elfeky, 2013).

\section{Objectives of the study}

1- To assess knowledge, attitudes, and practices regarding standard precautions concerning health care-associated infections (HAIs) among hemodialysis nurses in hemodialysis centers in Mosul hospital

2- To determine the relation between nurses knowledge, practice, and practices and their demographical characteristics

\section{Methodology \\ Design of the study}

To achieve the objective of the present research, a deceptive design type crosssectional study was conducted through 18th of February 2019 until 14th of February 2019.

\section{Setting of the study}

The study was conducted in two location in renal dialysis units at the Kidney Center at Al Salam Educational Hospital and Mosul General Hospital in Mosul City.

\section{The sample of the study}

The target population of this study consisted of nursing staff in renal dialysis units .A convenience sample include of 25 nursing who work in dialysis unit.

\section{The study instrument}

For the purpose of data collection, the researcher prepared questionnaires composted of four parts:

The first part included the demographic information for the research samples.

The second part included the knowledge of the nurses.

The third part included the attitudes.

The fourth part included the practices of the nursing staff in the dialysis units.

\section{Data collection}

The data were collected throughout the period from 18 of febroury-2019 to of march-2019

An interview mod was used for data collection.

\section{Data analysis}

The researcher fed the computer by all the data collected in the study using(statistical package for the social sciences) (SPSS) version (16).

The following statically approaches were applied:

1- Descriptive statistic

a-Frequency $(\mathrm{F})$

b-percentage $(\%)$

The results

Table(1):-Shows the characteristics of the research personnel. 
Mosul Journal of Nursing, Vol. 7, No. 2, 2019 ( 92-214 )

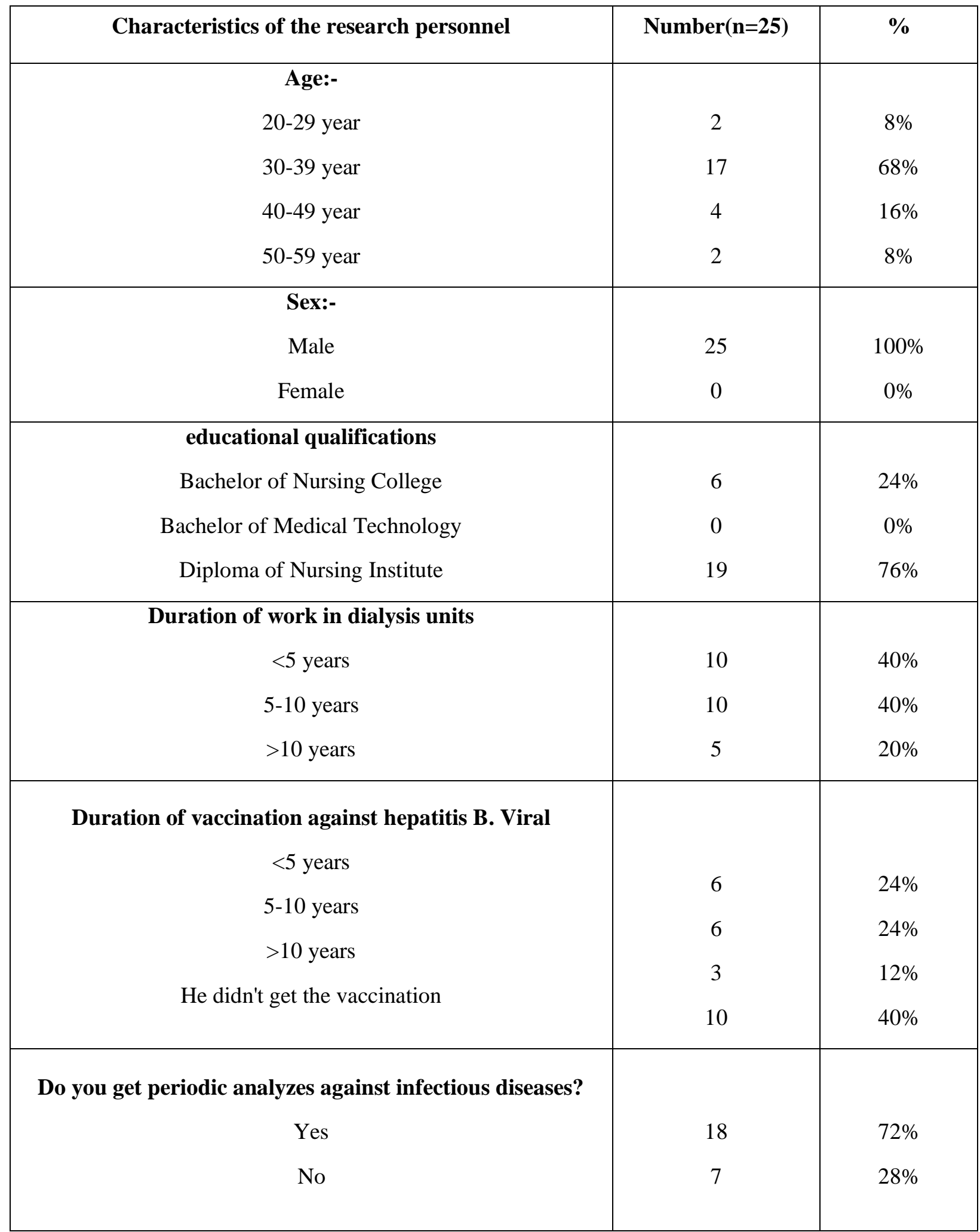

Table (1) shows that $68 \%$ of the research subjects were under the age of 40 , and $40 \%$ of the research sample had less than five years of functional experience. Also it shows that $12 \%$ of the individuals did not receive vaccination against viral hepatitis
B and $40 \%$ have been vaccinated for more than five years. In addition, $28 \%$ of the respondents said that the laundry center does not conduct periodic analyzes of infectious diseases. 
Table(2):- distribution of sample members according to their knowledge related to infection protection methods.

\begin{tabular}{|l|c|c|c|c|c|c|}
\hline \multirow{2}{*}{ Knowledge } & \multicolumn{2}{|c|}{ Agree } & \multicolumn{2}{c|}{ Disagree } & \multicolumn{2}{c|}{ I'm not sure } \\
\cline { 2 - 8 } & Number & $\%$ & Number & $\%$ & Number & $\%$ \\
\hline $\begin{array}{l}\text { 1-The hands of the medical staff can } \\
\text { carry the infection to the patients }\end{array}$ & 19 & $72 \%$ & 5 & $20 \%$ & 1 & $4 \%$ \\
\hline $\begin{array}{l}\text { 2-Washing hands are one of the } \\
\text { protection of infection }\end{array}$ & 25 & $100 \%$ & 0 & $0 \%$ & 0 & $0 \%$ \\
\hline $\begin{array}{l}\text { 3-Wear gloves, medical goggles, eye } \\
\text { freshness are essential to protect } \\
\text { against infection }\end{array}$ & 25 & $100 \%$ & 0 & $0 \%$ & 0 & $0 \%$ \\
\hline $\begin{array}{l}\text { 4-Intensive } \\
\text { procedures of the patient (patient } \\
\text { injection, installation of a catheter or } \\
\text { washing tube) are a risk factor for the } \\
\text { transmission of the disease }\end{array}$ & 22 & $88 \%$ & 2 & $8 \%$ & 1 & $4 \%$ \\
\hline
\end{tabular}

Table (3): shows the trends of research personnel to reduce the chances of infection.

\begin{tabular}{|l|c|c|c|c|c|c|}
\hline \multicolumn{1}{|c|}{ Attitudes } & \multicolumn{2}{|c|}{ Agree } & \multicolumn{2}{c|}{ Disagree } & \multicolumn{2}{c|}{ I'm not sure } \\
\cline { 2 - 7 } & Number & $\%$ & Number & $\%$ & Number & $\%$ \\
\hline $\begin{array}{l}\text { 1-Follow the infection protection } \\
\text { procedures and instructions to reduce } \\
\text { the chances of infection }\end{array}$ & 25 & $100 \%$ & 0 & $0 \%$ & 0 & $0 \%$ \\
\hline $\begin{array}{l}\text { 2-Hand washing and sterilization } \\
\text { reduces the chances of infection in the } \\
\text { patient }\end{array}$ & 25 & $100 \%$ & 0 & $0 \%$ & 0 & $0 \%$ \\
\hline $\begin{array}{l}\text { 3-Wear gloves, medical face mask, eye } \\
\text { freshness are essential to protect against } \\
\text { infection }\end{array}$ & 25 & $100 \%$ & 0 & $0 \%$ & 0 & $0 \%$ \\
\hline
\end{tabular}

Table (4) shows the applications of research personnel to reduce the chances of infection

\begin{tabular}{|l|l|l|l|l|l|l|l|l|}
\hline \multirow{2}{*}{ practices } & \multicolumn{2}{|l|}{ Always } & \multicolumn{2}{l|}{ Sometimes } & \multicolumn{2}{l|}{ scarcely } & \multicolumn{2}{l|}{ Don't better } \\
\cline { 2 - 10 } & Number & $\%$ & Number & $\%$ & Number & $\%$ & Number & $\%$ \\
\hline $\begin{array}{l}\text { 1-Wash my hands and } \\
\text { sterilize them before I } \\
\text { start the sick }\end{array}$ & 12 & $48 \%$ & 10 & $40 \%$ & 3 & $12 \%$ & 0 & $0 \%$ \\
\hline $\begin{array}{l}\text { 2-Wash my hands and } \\
\text { sterilize them before I go } \\
\text { to another patient }\end{array}$ & 9 & $36 \%$ & 11 & $44 \%$ & 5 & $20 \%$ & 0 & $0 \%$ \\
\hline $\begin{array}{l}\text { 3-I wash my hands and } \\
\text { sterilize } \\
\text { before they wear gloves }\end{array}$ & 11 & $44 \%$ & 8 & $32 \%$ & 5 & $20 \%$ & 1 & $4 \%$ \\
\hline $\begin{array}{l}\text { 4-Wear gloves when } \\
\text { there is direct contact } \\
\text { with the patient }\end{array}$ & 23 & $92 \%$ & 2 & $8 \%$ & 0 & $0 \%$ & 0 & $0 \%$ \\
\hline
\end{tabular}




\begin{tabular}{|c|c|c|c|c|c|c|c|c|}
\hline $\begin{array}{l}5 \text { - Wash my hands and } \\
\text { sterilize after removing } \\
\text { the gloves }\end{array}$ & 19 & $76 \%$ & 3 & $12 \%$ & 2 & $8 \%$ & 1 & $4 \%$ \\
\hline $\begin{array}{l}\text { 6- I change the gloves } \\
\text { when go to another } \\
\text { patient }\end{array}$ & 20 & $80 \%$ & 4 & $16 \%$ & 1 & $4 \%$ & 0 & $0 \%$ \\
\hline $\begin{array}{l}\text { 7-Wear eye protection } \\
\text { glasses when there is } \\
\text { direct contact with the } \\
\text { patient }\end{array}$ & 3 & $12 \%$ & 5 & $20 \%$ & 12 & $48 \%$ & 5 & $20 \%$ \\
\hline $\begin{array}{l}\text { 8. Wear the medical face } \\
\text { mask when there is } \\
\text { direct contact with the } \\
\text { patient }\end{array}$ & 10 & $40 \%$ & 8 & $32 \%$ & 5 & $20 \%$ & 2 & $8 \%$ \\
\hline $\begin{array}{l}\text { 9-Get rid of the needles } \\
\text { used to place them in the } \\
\text { container without } \\
\text { covering them }\end{array}$ & 21 & $84 \%$ & 3 & $12 \%$ & 1 & $4 \%$ & 0 & $0 \%$ \\
\hline
\end{tabular}

\section{Discussion the results}

Table (1) was found that $68 \%$ of the members of the research were under the age of forty, all of whom were male, which is consistent with the study of Alexandria (El-Enein NY,2011) and Khartoum (Salih L,et al,2011). Almost $40 \%$.

It was also found that $12 \%$ of the members of the research did not receive vaccination against viral hepatitis B and $40 \%$ were vaccinated for more than five years. Also, $28 \%$ of the research respondents said that the laundry center does not perform periodic analyzes of infectious diseases, Although many studies (Elzouki AN,2006) stressed the importance of giving vaccination to employees of dialysis units with the need for the work of periodic analyzes to reduce the chances of infection

The cuurent study revealed that research personnel have a good knowledge of infectious diseases and how they occur. This is in line with the results of the Khartoum study (Salih L,et al,2011) and the study of Italy (Bianco A,2013). However, they believed that infectious diseases were transmitted from the patient to the medical staff more than they were transferred from the medical staff to the patient What makes them more selfsufficient than their concern for the safety of the patient. Although $72 \%$ of the research know that the hands of the medical staff can carry the infection to the patient and agree that hand washing is one way to protect against infection, but almost $(36 \%)$, Of research personnel do not wash their hands and sterilize them before they go To another patient or after taking off the gloves. This contravenes the study of Italy (Bianco A,2013) which showed that

hand washing was more common among nurses who knew that it was one of the ways to protect against infection. And Khartoum(Salih L,et al,2011)

It was also found that most of the researchers $(100 \%)$ had positive attitudes to follow infection protection measures to reduce the chances of infectious diseases, which is a good indicator of compliance with infection protection measures if trained, and this is evidenced by many studies (Shimokura G,2006 - Elzouki AN,2006). 


\section{Mosul Journal of Nursing, Vol. 7, No. 2, 2019 ( 92-214 )}

Forty-eight percent of the researchers said they do not wear eye protection glasses when there is direct contact with the patient because they are not available in the laundry centers. It was also found that $(8 \%)$ of the researchers did not wear the medical mask when there was direct contact with the patient, despite knowing the importance, but most of the research (92\%) wearing gloves when there is direct contact with the patient and change when they go to another patient Which is consistent with the study of Alexandria (El-Enein NY,2011).

Many studies have shown that it is important for workers to receive training courses that provide them with information on ways to protect against infectious diseases and to train them to apply them (Bianco A,2013 - Elzouki AN,2006). It was found that more than half of the research population believed that there was a high risk of infectious diseases and this percentage was higher than in the study of America (Shimokura $G, 2006)$ This can be explained that workers in our laundry centers know that they do not apply the procedures to protect against infection correctly and therefore rose They have a belief that they may have infectious diseases.

\section{Conclusions:}

1-Nurses' knowledge of the infections associated with health care did not meet the purpose as a section of nursing staff did not adherence to hand hygiene practices .

2-Also the result showed that there are positive trend and knowledge of seriousness of transitional disease among nursing.

\section{Recommendations :}

This study recommend training programs for nurses in hemodialysis centers on:

1- The promotion of hygiene standards.

2 -Optimal use of personal protection against hospital infection.

3- Vaccinate all nursing of dialysis units against communicable diseases and periodically.

\section{References}

Association for professionals in infection control and epidemiology APIC (2010).
Guide to the elimination of infections in HD. Available at http://www.apic.org/Resource_/Eliminatio nGuideForm/7966d850-0c5a- 48ae-9090a1da00bcf988/File/APICHemodialysis.pdf

Benson, S., \& Powers, J. (2011). Your role in infection prevention. Nursing made incredibly easy, 9(3), 36-41.

Bianco A, Bova F, Nobile C, Pileggi C, Pavia M. Healthcare workers and prevention of hepatitis $\mathrm{C}$ virus transmission: exploring knowledge, attitudes and evidence-based practices in hemodialysis units in Italy. BMC Infectious Diseases 2013;13:76

Bouallègue, O., Naija, W., Said, H., Nouria, A., Jaidane, N., Dhidah, L., \& Boujaafar, N. (2013). P233: Incidence of ICU acquired nososcomial infections in University Hospital of Sahloul (SousseTunisia). Antimicrobial Resistance and Infection Control, 2(1), 1-1

David, O. M., \& Famurewa, O. (2010). Toward effective management of nosocomial infections in Nigerian hospitals-a review. Academic Arena, 2(5), 1-7.

Drummer, H. E. (2014). Challenges to the development of vaccines to hepatitis $\mathrm{C}$ virus that elicit neutralizing antibodies. Frontiers in microbiology, 5. Doi: 10.3389/fmicb. 00329.

Elamin, S., \& Abu-Aisha, H. (2011). Prevention of hepatitis B virus and hepatitis $\mathrm{C}$ virus transmission in hemodialysis centers: review of current international recommendations. Arab journal of nephrology and transplantation,4(1):35-47

El-Enein NY, El Mahdy HM. Standard precautions: a KAP study among nurses in the dialysis unit in a University Hospital in 


\section{Mosul Journal of Nursing, Vol. 7, No. 2, 2019 ( 92-214 )}

Alexandria, Egypt. The Journal of the Egyptian Public Health Association. 2011;86(1 and 2):3-10.

Elzouki AN, Esmeo MN, Samod M, Alagi B, Daw M, Forarra A, Ahmad I, Abodhair A. Prevalence of hepatitis B, C and Hiv infection in Libya. Liver International. 2006;26:20.

Eskander, H.G., Morsy, W.Y., \& Elfeky,H.A., (2013): Intensive Care Nurses 'Knowledge \& Practices regarding Infection Control Standard Precautions at a Selected Egyptian Cancer Hospital. Journal of Education and Practice, 4(19), 160- 174 .

Fresenius Medical Care (2012). ESRD Patients in 2011, A Global Perspective. Available at http://www.visionfmc.com/files/download/ ESRD/ESRD_Patients_in_2011.pdf

Jones. J., \& Fix, B. (2009). Textbook of Critical Care Notes, Clinical Pocket Guide,1st ed., F. A. Davis Company, Philadelphia, pp 110

Lawson, A. (2012). A study of the natural history of hepatitis $\mathrm{C}$ infection within a geographically determined population (Trent HCV study) (Doctoral dissertation, University of Nottingham.(

Liza, E., Kim, S., Rose, G., \& Stephen, B. (2012). Essential practice for infection prevention and control, guidance for nursing staff.

Longo, D. (2012). Dialysis in the Treatment of Renal Failure. In Harrison's principles of internal medicine, 18th ed., Chapter 281, New York: McGraw-Hill

Papadakis M., McPhee S., (2014): CURRENT Medical Diagnosis \& Treatment, 53 ed, p 664, McGraw-Hill Education.
Pozzetto, B., Memmi, M., Garraud, O., Roblin, X., \& Berthelot, P. (2014). Health careassociated hepatitis $\mathrm{C}$ virus infection. World journal of gastroenterology: WJG, 20(46), 17265

Salih L, Mohammed SI, Ali SE, Mohammed NF, Hassan EH, Ahmed MA, Rahamtalla AA, Abu-Aisha H. Staff knowledge, adherence to infection control recommendations and seroconversion rates in hemodialysis centers in Khartoum. Arab journal of nephrology and transplantation. 2011;4(1.(

Shimokura G, Weber DJ, Miller WC, Wurtzel H, Alter MJ. Factors associated with personal protection equipment use and hand hygiene among hemodialysis staff. American journal of infection control. 2006;34(3):100-7

Shimokura, G., Chai, F., Weber, D. J., Samsa, G. P., Xia, G. L., Nainan, O. V., \& Alter, M. J. (2011). Patient-care practices associated with an increased prevalence of hepatitis $\mathrm{C}$ virus infection among chronic hemodialysis patients. Infection Control, 32(05), 415-424.

Yu, C. I., \& Chiang, B. L. (2010): A new insight into hepatitis $C$ vaccine development. BioMed Research International. doi:10.1155/2010/548280.

Zhang, L., Gwinn, M., \& Hu, D. J., (2012): Viral hepatitis C gets personal--the value of human genomics to public health. Public health genomics, 16(4), 192-197. 